\title{
Biological control strategy for postharvest diseases of citrus, apples, grapes and strawberries fruits and application in Indonesia
}

\author{
Mutia Erti Dwiastuti ${ }^{*}$ (D) Loekas Soesanto ${ }^{2}$, Titistyas Gusti Aji ${ }^{1}$, Nirmala Friyanti Devy ${ }^{1}$ and Hardiyanto ${ }^{1}$
}

\begin{abstract}
Background: In Indonesia, the postharvest fruit loss is $25 \%$, so the economic loss from the export of various fruits is estimated at US\$ $58,966,861$. One of the causes for the loss is postharvest pathogens. Postharvest fruit rot is caused mainly by fungi, some of which produce mycotoxins harmful to human health. Therefore, in meeting the global food safety requirements, Indonesia should develop a biological control strategy for postharvest fruit diseases. This paper is a review based on observations, a literature review of postharvest biological control of citrus and other subtropical fruits, and an overview of strategies and prospects for their application in Indonesia.
\end{abstract}

Main body: The pathogens that cause diseases on citrus fruits, apples, grapes, and strawberries in Indonesia produce mycotoxins, namely Fusarium sp., Aspergillus terreus, Aspergillus sp., Penicillium sp., and Alternaria sp. The potential biological agents are from the yeast group, such as the Candida genera, the bacterial group, such as the Bacillus and Pseudomonas genera, and the fungal group, such as the Muscodor and Trichoderma genera.

Conclusion: Through mutually additive and synergistic multiple reduction methods in cooperation with the vanguards, postharvest disease control emphasizes disease prevention using several methods. Each method reduces the percentage of damage by a certain amount to produce highly effective controls.

Keywords: Citrus, Postharvest, Apples, Grapes, Strawberries, Mycotoxin, Microorganism agents, Botanical agents

\section{Background}

Indonesia is one of the tropical countries with the potential to develop fruits as a commodity, including citrus and other subtropical fruits (apples, grapes, and strawberries). The problem of fresh product quality and safety still needs attention. The low quality of fruits is mainly caused by a high microbial contamination, which pollutes various fruits in Indonesia because they are supported by tropical climatic conditions with high humidity levels. This contamination is economically detrimental and

\footnotetext{
*Correspondence: mutiaed@gmail.com

${ }^{1}$ Indonesian Citrus and Subtropical Fruit Research Institute, J. Raya

Tlekung No. 1, Junrejo, Batu City, East Java, Indonesia

Full list of author information is available at the end of the article
}

harmful to health, especially for diseases caused by fungi that produce mycotoxins. Mycotoxins are toxic organic compounds produced by the secondary metabolism of fungi that can interfere with human health clinically and pathologically (Ismaiel and Papenbrock 2015).

Pathogens that infect fruit products, including citrus, grapes, apples, and strawberries, may come from the field, while some emerge during postharvest. In addition, inadequate postharvest handling of fruits can result in physical damage, for example, bruising because of falling during transportation. Bruises or other physical damages on fruits make them easily infected with fungi. Postharvest and food losses are around 30\% of production in 
developing countries, especially those under humid climates (Bradford et al. 2018).

Some fungi that cause postharvest damage to citrus and other subtropical fruit crops (apples, grapes, and strawberries) include Botrytis, Penicillium, Mucor, Alternaria, Colletotrichum, Lasiodiplodia, Rhizopus, Fusarium, and Aspergillus (Pétriacq et al. 2018). In Indonesia, fungal contamination and low-safety assurance of various fruits are due to poor postharvest handling, including: (1) improper harvesting time, (2) over-packing and improper packing, (3) physical damages due to collisions and rough handling, and (4) chemical changes during the storage process. These factors result in the low-quality and lowsafety status of various fruits in Indonesia due to a high level of contamination (Miskiyah and Broto 2010).

Research on postharvest diseases and control of various fruits has not been widely carried out in Indonesia. However, many similar studies have been carried out abroad, as indicated by a large number of published research results (Wallace et al. 2018). Currently, the most effective control method is the use of chemical pesticides, but this method can create a single chemical resistance to fungal pathogens, if used continuously (Hawkins et al. 2019). The use of chemical pesticides demands more attention because of their potential toxicity to humans and the environment. In Indonesia, pesticide residues are found not only in fresh agricultural products but also in soil, water bodies, animal feed, and honey. Although the residue is still below the maximum residual limit, the use of agricultural chemicals needs to be monitored as they are toxic, persistent, and accumulative (Hendriadi et al. 2021). The food safety requirements of the global market encourage Indonesia to develop biological control strategies for postharvest diseases of fresh fruits. Therefore, this review was based on observations, biological control of postharvest diseases of citrus and other subtropical fruits, and an overview of strategies and prospects for their application in Indonesia.

\section{Main body \\ Postharvest diseases on citrus, apples, grapes, and strawberries in Indonesia}

Fungi, bacteria, and viruses can cause postharvest diseases of citrus, apples, grapes, and strawberries. Postharvest diseases can occur when the commodity has been harvested, but infections may also happen before harvesting when the pathogen is in a dormant state. Pathogens then develop and cause symptoms when conditions are favorable. Inventory-specific research showing postharvest diseases of citrus, apples, grapes, and strawberries has not been widely carried out in Indonesia. However, from the results of literature reviews, field and market observations (Dwiastuti and Fajrin 2014;
Widiastuti et al. 2015; Dwiastuti et al. 2016), and during the authors' visit to production centers of citrus, apples, grapes, and strawberries at different times, infections of Penicillium italicum, P. digitatum, Lasiodiplodia theobromae, Alternaria citri, Phomopsis citri, Geotrichum candidum, Pezicula malicorticis (Gloeosporium malicorticis), Glomerella cingulata, Physalospora abtusa, Podosphaera leucotricha, Mucor piriformis, P. expansum, Botrytis cinerea, Erysiphe necator, Colletotrichum gloesporiodes, Rhizopus stolonifer, Aspergillus sp., Penicillium sp., Phytophthora cactorum, Fusarium sp., Alternaria sp. were found in traditional markets and supermarkets (Table 1).

The types of fruits observed varied, from local to imported fruit varieties. More fungal contaminations were found in traditional markets than supermarkets. Lower fungal contaminations of fruits in supermarkets happen since supermarkets have air-conditioned storage areas, and fruits are sorted, cleaned, and covered with wrappers, reducing contact among fruits. In traditional markets, fruits are sold or stored as a reserve, placed in bamboo baskets without cooling space, while the temperature in the market tends to be high. In addition, fruits in traditional markets are not individually wrapped, so contact among fruit is possibly very high.

Some fungal diseases that contaminate citrus, apples, grapes, and strawberries in Indonesia including Fusarium sp., A. terreus, Aspergillus sp., Penicillium sp., and Alternaria sp. The types of mycotoxins found were patulin, ochratoxin, aflatoxin, deoxynivalenol, and others (Table 2). Each of these mycotoxins can cause quite dangerous effects on humans and animals. Table 2 shows that mycotoxins can cause mild to severe symptoms, including moderate-acute nausea, vomiting, diarrhea, abdominal pain, headaches, dizziness, fever, respiratory and circulatory failure, paralysis, seizures and death, to carcinogenic and mutagenic effects, plasma membrane disruption, protein synthesis inhibition, and inhibition on the anti-tumor, antiviral, antibacterial activities. However, in-depth knowledge about mycotoxins, especially in fruits in Indonesia, is still limited.

\section{Control management}

Similar to pre-harvest disease management in the field, postharvest disease control must also consider an integrated pest management strategy. Postharvest handling alone is insufficient for the product after harvest, but control measures during pre-harvest will significantly determine the health quality of the harvested fruits. Postharvest disease control is highly dependent on the initial condition of the commodity, meaning that plant health, planting area cleanliness, and several other treatments in the field determine the presence or absence of postharvest diseases. In addition, after entering the postharvest 
Table 1 Postharvest diseases of citrus and subtropical fruits in Indonesia. Source: Dwiastuti unpublished (UP): Field and market observations during visits to production centers of citrus, apples, grapes, and strawberries at different times

\begin{tabular}{|c|c|c|c|c|c|}
\hline \multirow[t]{2}{*}{ Diseases } & \multirow[t]{2}{*}{ Pathogen } & \multirow[t]{2}{*}{ Location } & \multicolumn{2}{|c|}{$\begin{array}{l}\text { Found } \\
\text { on }\end{array}$} & \multirow[t]{2}{*}{ References } \\
\hline & & & TM & SM & \\
\hline \multicolumn{6}{|l|}{ Citrus } \\
\hline Green mold & Penicillium italicum & $\begin{array}{l}\text { Midlands and highlands in East Java, West } \\
\text { Java, Bali, East Nusa Tenggara }\end{array}$ & $\mathrm{F}$ & $\mathrm{F}$ & Soesanto (2006), Dwiastuti UP \\
\hline Blue mold & P. digitatum & $\begin{array}{l}\text { Midlands and highlands in East Java, West } \\
\text { Java, Bali, East Nusa Tenggara }\end{array}$ & $\mathrm{F}$ & $\mathrm{F}$ & Soesanto (2006), Dwiastuti UP \\
\hline Stem end rot & Lasiodiplodia theobromae & $\begin{array}{l}\text { All altitudes of East Java, Central Java, West } \\
\text { Java, Bali, East Kalimantan, West Kaliman- } \\
\text { tan, East Sulawesi, East Nusa Tenggara }\end{array}$ & $\mathrm{F}$ & NF & Soesanto (2006), Dwiastuti and Aji (2021) \\
\hline Circular rot & Alternaria citri & East Java & $\mathrm{F}$ & NF & Soesanto (2006), Dwiastuti UP \\
\hline Stem end rot & Phomopsis citri & Market, storage & $\mathrm{F}$ & $\mathrm{F}$ & Soesanto (2006) \\
\hline Sour mold & Geotrichum candidum & Market, storage & $\mathrm{F}$ & $\mathrm{F}$ & Soesanto (2006) \\
\hline \multicolumn{6}{|l|}{ Apples } \\
\hline Apple anthracnose & $\begin{array}{l}\text { Pezicula malicorticis (Gloe- } \\
\text { osporium malicorticis) }\end{array}$ & East Java, West Java, East Nusa Tenggara & $\mathrm{F}$ & NF & Dwiastuti UP \\
\hline Bitter rot & Glomerella cingulata & East Java, Central Java & $\mathrm{F}$ & F & Soesanto (2006) \\
\hline Black rot & Physalospora abtusa & East Java, Central Java & $\mathrm{F}$ & $\mathrm{F}$ & Soesanto (2006) \\
\hline Dry rot & Alternaria sp. & Yogyakarta & $\mathrm{F}$ & NF & Widiastuti et al. (2015) \\
\hline Powdery mildew & Podosphaera leucotricha & East Java, West Java, East Nusa Tenggara & $\mathrm{F}$ & NF & Dwiastuti UP \\
\hline Mucor rot & Mucor piriformis & East Java & $\mathrm{F}$ & NF & Dwiastuti UP \\
\hline Blue mold & P. expansum & East Java & $\mathrm{F}$ & F & Soesanto (2006), Dwiastuti UP \\
\hline \multicolumn{6}{|l|}{ Grapes } \\
\hline Gray mold & Botrytis cinerea & East Java, Bali & $\mathrm{F}$ & NF & Soesanto (2006), Dwiastuti UP \\
\hline Powdery mildew & Erysiphe necator & East Java, Bali & $\mathrm{F}$ & NF & Dwiastuti UP \\
\hline Anthracnose & Colletotrichum gloesporiodes & East Java, Bali & $\mathrm{F}$ & NF & Dwiastuti UP \\
\hline Rhizopus rot & Rhizopus stolonifer & East Java, Bali & $\mathrm{F}$ & NF & Soesanto (2006), Dwiastuti UP \\
\hline Dry rot & Aspergillus sp. & Central Java & $\mathrm{NF}$ & $\mathrm{F}$ & Widiastuti et al. (2015), Dwiastuti UP \\
\hline Blue mold & Penicillium sp. & Market, storage & $\mathrm{F}$ & $\mathrm{F}$ & Soesanto (2006) \\
\hline \multicolumn{6}{|l|}{ Strawberries } \\
\hline Gray mold & B. cinerea & $\begin{array}{l}\text { East Java, Central Java, West Java, Bali, } \\
\text { North Sumatera }\end{array}$ & $\mathrm{F}$ & $\mathrm{F}$ & Dwiastuti UP \\
\hline Rhizopus rot & R. stolonifer & East Java & $\mathrm{F}$ & NF & Dwiastuti UP \\
\hline Phytophthora rot & Phytophthora cactorum & East Java & $\mathrm{F}$ & NF & Dwiastuti and Fajrin (2014) \\
\hline Anthracnose & C. gloesporiodes & $\begin{array}{l}\text { East Java, Central Java, West Java, Bali, } \\
\text { North Sumatera, }\end{array}$ & $\mathrm{F}$ & $\mathrm{F}$ & Dwiastuti and Fajrin (2014) \\
\hline Fusarium rot & Fusarium sp. & East Java & $\mathrm{F}$ & NF & $\begin{array}{l}\text { Dwiastuti and Fajrin (2014), Dwiastuti et al. } \\
\text { (2016) }\end{array}$ \\
\hline Alternaria rot & Alternaria sp. & East Java & $\mathrm{F}$ & $\mathrm{NF}$ & Dwiastuti UP \\
\hline
\end{tabular}

$\mathrm{TM}=$ Traditional markets, $\mathrm{SM}=$ supermarkets, $\mathrm{F}=$ found, $\mathrm{NF}=$ not found

period, disease progression is highly dependent on management techniques from harvesting to transportation or storage at the consumer level.

Disease control for citrus, apples, grapes, and strawberries is usually carried out from generative growth and ends one month before harvest to avoid residue on the fruits (Sumiati and Julianto 2017). Generally, fruit orchards in Indonesia are located far from consumers. Therefore, fruits are transported from the packaging station in the production center to various destinations using various vehicles. They can even be transported several times to reach the final destination (Prabawati 2009). This causes farmers to sell on a wholesale basis. As such, sorting is not carried out by farmers but by collectors, traditional market traders, and retail traders by removing rotten fruits in simple to modern ways.

However, not all farmers or traditional traders in Indonesia carry out postharvest handling, such as washing, 
Table 2 Mycotoxins produced by fungi that cause postharvest diseases on citrus and subtropical fruits and their effects

\begin{tabular}{|c|c|c|c|c|}
\hline \multirow[t]{2}{*}{ Pathogen } & \multicolumn{2}{|l|}{ Mycotoxin } & \multicolumn{2}{|l|}{ Effects } \\
\hline & Mycotoxin & References & Effects on humans & References \\
\hline Fusarium sp. & $\begin{array}{l}\text { Deoxynivalenol, } 12 \text { toxin, zearalenone, } \\
\text { moniliformin, } \\
\text { Fumonisin }\end{array}$ & Rahayu (2006) & $\begin{array}{l}\text { Acute temporary nausea, vomiting, diarrhea, } \\
\text { abdominal pain, headache, dizziness, and } \\
\text { fever }\end{array}$ & Sobrova et al. (2010) \\
\hline Aspergillus terreus & Citreoviridin, terreic acid, patulin & Rahayu (2006) & $\begin{array}{l}\text { Aspergillosis, respiratory and circulatory } \\
\text { failure, paralysis, seizures and death }\end{array}$ & Lass-Florl et al. (2005) \\
\hline Aspergillus sp. & $\begin{array}{l}\text { Aflatoxins, kojic acid, aspergillic acid, cyclopi- } \\
\text { azonic acid, patulin, stereoviridin, fumigatin, } \\
\text { ochratoxins, sterigmatocystin, viriditoxin, } \\
\text { citrinin, palmotoxin, rubratoxin }\end{array}$ & Rahayu (2006) & $\begin{array}{l}\text { Carcinogenic, mutagenic, teratogenic, and } \\
\text { immunosuppressive for humans }\end{array}$ & Lanier et al. (2020) \\
\hline Penicillium sp. & $\begin{array}{l}\text { Patulin, ochratoxin, citrinin, luteoskirin, } \\
\text { tremorgenic, rubratoxin, mycophenolate, } \\
\text { griseofulvin, phenytoin, colonic acid }\end{array}$ & Rahayu (2006) & $\begin{array}{l}\text { Plasma membrane disruption; protein } \\
\text { synthesis inhibition; } \mathrm{Na}^{+} \text {-coupled inhibition; } \\
\text { amino acid transport, transcription and trans- } \\
\text { lation disorders; DNA synthesis inhibition; } \\
\text { and inhibition in the production of interferon } \\
\text { y type } 1 \text { T-helper cells }\end{array}$ & $\begin{array}{l}\text { Pal et al. (2017), } \\
\text { Ramalingam et al. } \\
\text { (2019) }\end{array}$ \\
\hline Alternaria sp. & Tenuazonic acid & Rahayu (2006) & $\begin{array}{l}\text { Causing Onyalai disease, causing chronic } \\
\text { and acute effects by inhibiting anti-tumor, } \\
\text { antiviral, antibacterial activities, and causing } \\
\text { mutagenic activities }\end{array}$ & Zain (2011) \\
\hline
\end{tabular}

sorting, and pre-cooling (Siswadi 2007). As a result, many of them are not aware of whether the fruit carries spores or parts of microbes that can develop and become new sources of infection. In addition, most of the local market traders (traditional markets) in Indonesia only select fruits based on their respective grades and put them in the same container; there is no separation among fruits. The exception is only for packaging for modern markets (supermarkets), which require more stringent terms and standards for the safety of fruit to be marketed (Siswadi 2007).

Postharvest disease control using physical method has been recommended in Indonesia, but not all can apply it to maintain fruits quality. The method used includes low-temperature management and modification of the storage room atmosphere using reduced oxygen, elevated carbon dioxide, heat treatment (hot air or immersion), or radiation (Sukasih and Setyadjit 2019). Utilizing chemicals to control the postharvest disease is considered the most effective. However, its application depends on the type of marketing and infection that occurs. For example, in citrus with a long shelf life, there should be additional safe chemical treatment to prevent the germination of fungal spores. Conversely, for strawberries that have a very short shelf life, it seems that postharvest disease control treatment is prioritized on controlling just before harvest in the field (Sudjatha and Wisaniyasa 2017).

Alternative modern techniques used to minimize losses due to postharvest diseases in developed countries are physical, biochemical, biological (Qadri et al. 2020), and breeding for resistance (Pétriacq et al. 2018). These modern techniques can be used as a reference for controlling postharvest diseases in Indonesia. Until now, there is no information on citrus, apple, grape, and strawberry varieties that are resistant to postharvest diseases.

Biochemical techniques for modern postharvest disease control are aimed at suppressing the use of pesticides and minimizing the side effects of fungicide resistance in major fungal pathogens such as Penicillium, Monilinia, Botrytis, and other common pathogens (Qadri et al. 2020). The technique being tried out involves genetic transformation with the application of fungicidal dsRNA. de Oliveira Filho et al. (2021) reviewed the results of research on the external application of synthetic fungicide dsRNA on fruits, which is safer for controlling postharvest fruit diseases, as a new generation of sustainable and environmentally friendly products. Several studies have been carried out by spraying or soaking fruit surfaces with RNA interference (RNAi) to control postharvest fungi of fruits, particularly B. cinerea (Wang et al. 2016) and Fusarium spp. (Gu et al. 2019) which causes postharvest losses on strawberries, grapes, and other fruits. This new fungicide with RNAi technology has greater specificity and efficiency. External application of double-stranded RNA (dsRNA), small interference RNA (siRNA), or hairpin RNA (hpRNA), resulting in post-transcriptional gene silencing, has emerged as a promising strategy for controlling phytopathogens (Islam and Sherif 2020). Nanomaterials have also been used as a new generation in postharvest technology in general and disease management in particular (Roberto et al. 2019). Exogenous application of calcium-based chemicals helps 
stabilize plant cell walls, maintaining fruit quality (Rodriguez et al. 2019). Chitosan solution (0.5 and 1\%) was effective for maintaining high quality and preventing fungal pathogens in oranges during cold storage with good chemical and physical quality (Khalil Bagy et al. 2021). In addition, Youssef et al. (2020) reported that potassium bicarbonate $(\mathrm{PB})$, sodium silicate solution $(\mathrm{SSi})$ and calcium chelate $(\mathrm{CCh})(1 \%)$ were effective in inducing resistance to gray mold disease in table grapes and reduced disease incidence by 43,50 , and $41 \%$, respectively. The salt solution acts as an antimicrobial agent against the gray mold of table grapes so that it can increase the natural host resistance associated with an increase in the antioxidant system. From this study, it was proved that the activity of the enzymes superoxide dismutase (SOD), ascorbate peroxidase (APX) and peroxidase (POD) increased with the above salt treatment.

Various physical techniques with refrigeration, cold atmosphere storage, low pressure storage, and modified atmosphere storage are used to control postharvest disease. The physical technique of heat treatment is considered the most effective, especially to treat fungal diseases and chilling injury. In addition, UV treatments (UV-C, UV-B, and UV-A) are used to sterilize commodities, reduce spoilage due to microorganisms, extend shelf life, and maintain fruit quality. UV treatment exposes fruit and vegetable commodities for a period of time under a UV lamp bank, with maximum emission at $254 \mathrm{~nm}$. UV-C treatment has been shown to be effective for controlling the most common postharvest pathogens (Civello et al. 2006). Several studies have also proven that $\mathrm{UV}-\mathrm{C}$ radiation is effective not only because of its disinfecting effect, but also because it can stimulate plant defenses. Forges et al. (2020) stated that UV-C radiation was efficient in reducing disease progression in many species, including strawberries (Fragaria $\times$ ananassa). Infection on leaf against powdery mildew and on fruit against Rhizopus spp. were greatly decreased due to the UV-C effect. Besides that, it also has an impact on the initiation of flowering and fruit development, increasing the physical integrity of strawberries in storage, although it does not increase the shelf life of strawberries.

Postharvest disease management using biological agents has been studied extensively. By involving natural enemies of the pathogen to be targeted, the population of the pathogen can be suppressed through restriction of normal growth or activity. In addition, volatile compounds are usually applied on a commercial scale for flavoring and seasoning in foods, which greatly reduces the incidence of microbial pathogens. This volatile compound has various properties such as antiprotectant, antimicrobial, less harmful to mammals, environmentally friendly, and can be used as an alternative to chemical fungicides (Abo-Elyousr et al. 2021). Plants are a large reservoir of natural compounds that harbor fungicidal activity with the potential to replace synthetic fungicides. Many species produce volatile substances and essential oils that can serve as antifungal or antimicrobial preservatives for fruits and other harvested commodities. Thus, combining multiple treatment options can offer stakeholders and producers a more consistent, durable, practical, and sustainable solution for postharvest disease control.

The breeding techniques involved in increasing fruit resistance and postharvest disease control is priming. This is a novel adaptive strategy by inducing plant immune systems to have protection against disease (Pétriacq et al. 2018). Priming can be long lasting and can be maintained throughout the plant life cycle (Luna et al. 2016) and can even be transmitted to the next generation (Rasmann et al. 2012), therefore representing a type of plant immunological memory. This phenomenon is characterized by increased activation of induced defense mechanisms. Stimuli can be from pathogens, beneficial microbes, or arthropods, as well as chemical and abiotic cues, thus triggering priming formation that acts as a warning signal. After perception of a stimulus, changes can occur in plants at physiological, transcriptional, metabolic, and epigenetic levels. This phase is called the priming of defense phase and is understood as the adaptive part of induced resistance (IR) (Mauch-Mani et al. 2017). After subsequent challenges, plants effectively mount a faster and/or stronger defense response that defines a postchallenge prime and results in increased resistance and/or stress tolerance. The potential for future use is very high and inexpensive; thus, detailed research support is needed.

\section{Alternative biological control}

Antagonistic microorganisms have been found to suppress the development of disease on the surface of the fruits. Controlling postharvest diseases of citrus fruit using antagonistic microorganisms is carried out in two ways: (a) using natural epiphytic antagonists that are already on the surface of the fruit; and (b) artificial introduction of selective microbial antagonists that control postharvest diseases. There have been many studies showing that antagonistic microorganisms are effective in controlling postharvest disease of citrus, apples, grapes, and strawberries, with various application methods (Table 3). In addition, some antagonistic microbial products have been developed from actively infected fruits. Until now, biological control has not completely replaced the use of fungicides or other chemicals in postharvest disease control. In the future, it is hoped that biological control can become more established as part of an 
Table 3 Microorganism agents used for the successful control of postharvest diseases of citrus, apples, grapes, and strawberries

\begin{tabular}{|c|c|c|c|}
\hline Microorganism agents & Pathogen & Mechanism of action & References \\
\hline \multicolumn{4}{|l|}{ Yeast } \\
\hline Candida saitoana & Penicillium italicum & $\begin{array}{l}\text { Competition for nutrient and space, } \\
\text { direct parasitism }\end{array}$ & El Ghaouth et al. (2002) \\
\hline C. oleophila & $\begin{array}{l}\text { P. digitatum } \\
\text { Botrytis cinerea } \\
\text { Colletotrichum gloeosporioides } \\
\text { P. expansum } \\
\text { P. italicum } \\
\text { Rhizopus stolonifer }\end{array}$ & Induction of resistance & $\begin{array}{l}\text { Droby et al. (2002), Liu et al. (2007), } \\
\text { Spadaro (2012) }\end{array}$ \\
\hline C. sake & $\begin{array}{l}\text { P. digitatum } \\
\text { B. cinerea } \\
\text { P. expansum }\end{array}$ & ND & Spadaro (2012) \\
\hline C.ernobii & Lasiodiplodia theobromae & Induction of resistance & Spadaro (2012) \\
\hline Kloeckera apiculata & P. italicum & Competition for nutrient and space & Long et al. (2006) \\
\hline Wickerhamomyces anomalus & P. digitatum & Antibiosis & Platania et al. (2012) \\
\hline Cryptococcus laurentii & $\begin{array}{l}\text { Alternaria alternata } \\
\text { B. cinerea } \\
\text { R. stolonifer }\end{array}$ & Antagonist & Wei et al. (2014) \\
\hline Pichia guilliermondii & $\begin{array}{l}\text { A. alternata } \\
\text { B. cinerea } \\
\text { P. digitatum } \\
\text { P. expansum } \\
\text { P. italicum } \\
\text { R. stolonifer }\end{array}$ & Antagonist & Sui et al. (2015) \\
\hline $\begin{array}{l}\text { Schwanniomyces vanrijiae combi- } \\
\text { nation and ethanolic extracts of } \\
\text { propolis (EEP) }\end{array}$ & $\begin{array}{l}\text { P. digitatum } \\
\text { Mucor fructigena }\end{array}$ & Antibiosis, antioxidant & Abo-Elyousr et al. (2021) \\
\hline Galactomyces geotrichum & M. fructigena & Antagonist & Madbouly et al. (2020) \\
\hline Pichia kudriavzevii & M. fructigena & Antagonist & Madbouly et al. (2020) \\
\hline Meyerozyma caribbica & C. gloeosporioides & Antagonist & $\begin{array}{l}\text { Navarro-Herrera and Ortíz-Moreno } \\
\text { (2020) }\end{array}$ \\
\hline Rhodosporidium paludigenum & P. digitatum & ND & Zhang et al. (2021) \\
\hline \multicolumn{4}{|l|}{ Bacteria } \\
\hline Bacillus subtilis & $\begin{array}{l}\text { P. digitatum } \\
\text { A. citri } \\
\text { B. cinerea } \\
\text { C. gloeosporioide } \\
\text { L. theobromae } \\
\text { P. expansum } \\
\text { P. italicum } \\
\text { Phomopsis citri }\end{array}$ & Antibiosis & Mohammadi et al. (2017) \\
\hline B. amyloliquefaciens & $\begin{array}{l}\text { B. cinerea } \\
\text { C. gloeosporioides } \\
\text { L. theobromae } \\
\text { P. digitatum } \\
\text { P. expansum } \\
\text { P. italicum } \\
\text { R. stolonifer }\end{array}$ & Antibiosis & Calvo et al. (2017) \\
\hline Streptomyces sp. CACIS-1.5CA & $\begin{array}{l}\text { Colletotrichum sp. } \\
\text { Alternaria sp. } \\
\text { Aspergillus sp. } \\
\text { Botrytis sp. } \\
\text { Rhizoctonia sp. } \\
\text { Rhizopus sp. }\end{array}$ & Antagonist, antibiosis & Evangelista-Martínez et al. (2020) \\
\hline B. thuringiensis & Guignardia citricarpa & Antibiosis, induction of resistance & Lucon et al. (2010) \\
\hline B. licheniformis & C. gloeosporioides Dothiorella gregaria & Antibiosis, induction of resistance & Spadaro (2012) \\
\hline B. pumilus & B. cinerea & Antibiosis, induction of resistance & Abd-El-Kareem et al. (2021) \\
\hline Burkholderia cepacia & C.musae & Antibiosis & Spadaro (2012) \\
\hline
\end{tabular}


Table 3 (continued)

\begin{tabular}{|c|c|c|c|}
\hline Microorganism agents & Pathogen & Mechanism of action & References \\
\hline B. gladioli & $\begin{array}{l}\text { P. digitatum } \\
\text { P. expansum }\end{array}$ & Antibiosis & Spadaro (2012) \\
\hline B. glathei & P. digitatum & Antibiosis & Spadaro (2012) \\
\hline Brevundimunas diminuta & C. gloeosporioides & Antibiosis & Spadaro (2012) \\
\hline Enterobacter aerogenes & A. alternata & Antibiosis & Nabi et al. (2017) \\
\hline E. cloacae & R. stolonifer & Antibiosis & Spadaro (2012) \\
\hline Pantoea agglomerans & $\begin{array}{l}\text { Penicillium spp. } \\
\text { P. digitatum } \\
\text { P. expansum } \\
\text { P. italicum } \\
\text { R. stolonifer }\end{array}$ & $\begin{array}{l}\text { Antibiosis, triggers } \mathrm{H}_{2} \mathrm{O}_{2} \text { production } \\
\text { and enzymatic activities }\end{array}$ & Spadaro (2012) \\
\hline Pseudomonas aeruginosa & Erwinia carotovora & Antibiosis & Spadaro (2012) \\
\hline P. серасіа & $\begin{array}{l}\text { B. cinerea } \\
\text { P. digitatum } \\
\text { P. expansum }\end{array}$ & Antibiosis & Spadaro (2012) \\
\hline P. fluorescens & $\begin{array}{l}\text { B. cinerea } \\
\text { P. expansum }\end{array}$ & Antibiosis & Wallace et al. (2018) \\
\hline P. corrugata & Monilinia fructicola & Induction of resistance & Benhamou (2004) \\
\hline P. putida & E. carotovora & Antibiosis & Spadaro (2012) \\
\hline P. syringae & $\begin{array}{l}\text { B. cinerea } \\
\text { G. candidum } \\
\text { M. fructicola } \\
\text { P. digitatum } \\
\text { P. expansum } \\
\text { P. italicum }\end{array}$ & Antibiosis & Spadaro (2012) \\
\hline Serratia plymuthica & Penicillium spp. & $\begin{array}{l}\text { Antibiosis and competition for } \\
\text { nutrient }\end{array}$ & Meziane et al. (2006) \\
\hline \multicolumn{4}{|l|}{ Fungi } \\
\hline Verticillium lecanii & P. digitatum & Induction of resistance & Benhamou (2004) \\
\hline Aureobasidium pullulans & $\begin{array}{l}\text { P. digitatum } \\
\text { B. cinerea } \\
\text { P. expansum } \\
\text { R. stolonifer }\end{array}$ & Antibiosis & Spadaro (2012) \\
\hline Muscodor albus & $\begin{array}{l}\text { P. digitatum } \\
\text { P. expansum } \\
\text { B. cinerea } \\
\text { Geotrichum citri-aurantii }\end{array}$ & Production of volatile compounds & Mercier and Smilanick (2005) \\
\hline Acremonium breve & B. cinerea & ND & Spadaro (2012) \\
\hline T. harzianum & $\begin{array}{l}\text { B. cinerea } \\
\text { R. stolonifer } \\
\text { P. expansum }\end{array}$ & Antagonist & Sharma et al. (2009) \\
\hline T. viride & $\begin{array}{l}\text { P. digitatum } \\
\text { B. cinerea }\end{array}$ & Antagonist & Sharma et al. (2009) \\
\hline Trichoderma spp. & L. theobromae & Antagonist & Sharma et al. (2009) \\
\hline
\end{tabular}

integrated program of controlling major postharvest diseases caused by fungi.

\section{Yeast as a biocontrol agent}

Yeast is one of the best and safe alternative ingredients for the biological control of citrus, apples, grapes, and strawberries. The mechanism of action of yeast in postharvest disease inhibition includes competition for nutrients and the ability to form biofilms and colonize wounds (Parafati et al. 2016). Furthermore, yeast can produce extracellular polysaccharides, increasing its resistance and limiting the growth of pathogenic propagules. In addition, yeast can use nutrients quickly and reproduce at high speed (Sharma et al. 2009). Yeast can also tolerate common pesticides such as imazalil, tiabendazole, pyrimethanil, or fludioxonil (Perez et al. 2017). Several types of yeast were successful in controlling citrus fruit rot disease, namely C. saitoana, C. famata, C. oleophila, C. sake, C. 
ernobii, Kloeckera apiculata, Wickerhamomyces anomalus, Cryptococcus laurentii, and Pichia guilliermondii (Platania et al. 2012). Results of the latest invention showed that several yeasts, including Meyerozyma caribbica, have the potential as a promising biocontrol gene for the prevention of anthracnose (C. gloeosporioides) in passion fruit (Navarro-Herrera and Ortíz-Moreno 2020). Abo-Elyousr et al. (2021) reported that S. vanrijiae was also effective to control $P$. digitatum on lemon. Inhibition of the conidia of $M$. fructigena from apples in vitro was demonstrated by S. vanrijiae, G. geotrichum, and Pichia kudriavzevii from 67.6 to $89.2 \%$ and significantly reduced the incidence of disease, respectively, up to 84.02-89.5, $80,1-86.9,56.3-86.9 \%$ than the control (Madbouly et al. 2020). However, despite many reports regarding yeast as a biological control agent, the number of commercial products available is still limited in Indonesia.

\section{Bacteria as a biocontrol agent}

The use of bacteria for postharvest disease control of fruits is one step ahead. Its products are available as biofungicides. It is easy to obtain bacteria as control material because they are available abundantly in nature. In most plant species, rhizosphere bacteria can be isolated from the surface of plant tissues, soil, roots, and various plants of the rhizosphere. In addition, there are endophytic bacteria in demand as biocontrol agents because they can colonize plant tissues to form internal defenses against pathogens (Liu et al. 2013).

Antagonistic bacteria are well known for producing substances with antifungal and antibacterial properties (Yánez-Mendizábal et al. 2011). Bacillus and Pseudomonas genera are effective antagonists in controlling pathogens because they contain the chitinase enzyme that can hydrolyze the $3-1,4$ bonds among $\mathrm{N}$-acetylglucosamine (NacGlc) in chitin; this polysaccharide polymer makes up the cell walls of several pathogenic fungi and the exoskeleton of invertebrates. Therefore, chitinase is well known for its antifungal or microbial properties (Yu et al. 2008). Mohammadi et al. (2017) reported the isolation of extracellular enzymatic activity of potential bacteria (B. subtilis, B. pumilus, B. megaterium, and Agrobacterium radiobacter) to control blue mold diseases in citrus fruit ( $P$. digitatum). Abd-El-Kareem et al. (2021) also reported the effectiveness of B. pumilus on strawberry black rot disease (Rhizoctonia solani, F. solani, and Phytium sp.). The results showed that the chitinase, glucanase, and protease enzyme reacted positively to control pathogenic fungi, except for the bacteria $A$. radiobacter. The inhibitory mechanism of bacteria is classified as antibiosis. Some of the antibiotics produced by antagonistic bacteria are iturin, an antifungal produced by $B$. subtilis, and pyrrolnitrin produced by $P$. cepacia (Layton et al.
2011). The process of antibiosis can also occur through the production of low molecular weight compounds produced by antagonistic bacteria, called volatile organic compounds (VOCs). This compound is active in low concentrations in several chemicals, such as alcohols, aldehydes, ketones, esters, lactones, terpenes, and sulfur compounds. Due to their volatility, these compounds can safely be transported long distances in heterogeneous environments in the form of solid, liquid, or gaseous compounds. He et al. (2020) reported that VOCs produced by $B$. methylotrophicus $\mathrm{BCN} 2$ and $B$. thuringiensis BCN10 were effective in controlling and suppressing the mycelium of five postharvest pathogens isolated from loquat fruits, namely $F$. oxysporum, Botryosphaeria sp., $T$. atroviride, $C$. oriumes, and $P$. expansum based on in vitro and in vivo experiments. The final results showed that the loquats remained fresh for ten days significantly. Significant progress was also found in the control of postharvest citrus diseases with the use of antagonistic bacteria such as B. subtilis, B. amyloliquefaciens, P. fluorescens, $B$. thuringiensis, B. licheniformis, B. pumilus, B. cepacia, B. gladioli, B. glathei, B. diminuta, E. aerogenes, E. cloacae, . agglomerans, $P$. aeruginosa, $P$. corrugata, P. putid, P. syringae, and S. plymuthica (Table 2). P. fluorescens produces secondary metabolites products include: phenazine-1-carboxylic acid and 2,4-diacetylphloroglucinol, polysaccharides, and many others (Soesanto 2009).

Currently, there are 3 commercial Pseudomonas formulations are listed in the USA: Bio-Save $10 \mathrm{LP}$, Bio-Save 11 LP, and BlightBan A506 (Stockwell and Stack 2007). Bio-Save $10 \mathrm{LP}$ and Bio-Save $11 \mathrm{LP}$ contain the P. syringae strains ESC-10 and ESC-11, respectively. This product is applied in packaging stations to prevent postharvest fungal diseases on oranges, pome, stone fruit, and potatoes during storage. BlightBan A506 contains P. fluorescens strain A506 and is mainly applied to pear and apple trees during bloom to suppress bacterial blight. This biocontrol product can inhibit fungal diseases with moderate to very good criteria. In addition, the procedure is relatively easy to implement and can be integrated with conventional products for disease control. In 2020, it was reported that Streptomyces sp. CACIS-1.5CA was effective against the pathogenic fungi Colletotrichum sp., Alternaria sp., Aspergillus sp., Botrytis sp., Rhizoctonia sp., and Rhizopus sp. with percentages ranging from 30 to 63\% (Evangelista-Martínez et al. 2020).

\section{Fungi as a biocontrol agent}

Utilization of antagonistic fungi to control postharvest diseases is less developed than those of yeast and bacteria. Antagonistic fungi show a broad spectrum of disease control but have volatile antimicrobial compounds (Mercier et al. 2007). Six antagonistic fungi (V. lecanii, 
A. pullulans, M. albus, A. breve, T. harzianum, T. viride, and Trichoderma spp.) were reported to control citrus and subtropical fruit diseases (Table 2). The fungi biofumigant $M$. albus, which produces specific low molecular weight volatiles, has been used to fumigate lemons in storehouses and has successfully controlled green fungal pathogens and acid rot (Mercier and Smilanick 2005). This fungus produces 28 volatile organic compounds that exhibit some inhibitory effects against fungal and bacterial pathogens (Strobel et al. 2001). This antagonism occurs due to antimicrobial metabolites (Verma et al. 2007). The potential as fungal antagonists can be increased continuously with improved isolation, formulation, and application methods, particularly in the postharvest environment.

\section{Strategy of implementing biological control for postharvest diseases in Indonesia}

The application of biological control in postharvest diseases of citrus, apples, grapes, and strawberries has not been studied on a large scale. In traditional Indonesian markets, biological control is rarely implemented. Biolog- applied in the supply chain from harvest to market to prevent cross-contamination and the spread of pathogenic contamination to the downstream process. This method was based on intervention using technology at critical points during the harvesting, handling, storage, shipping, and marketing processes, by integrating a field-to-supermarket approach. The concept of postharvest disease control was about using several methods, each of which reduces the percentage of damage by a certain amount, mutually additive and synergistic to produce control with 97-99\% effectiveness (Fig. 1).

The following is a strategy for implementing postharvest disease biological control in Indonesia. Through mutually additive and synergistic multiple reduction methods in cooperation with the vanguards, postharvest disease control emphasizes disease prevention using several methods. Each method reduces the percentage of damage by a certain amount to produce highly effective controls carried out sequentially or together (Fig. 2). This multi-step method is divided into preventive and curative controls. Preventive control strategies are as follows:

Action $1=$ reducing the inoculum level through sanitation and/or careful harvesting and handling

Action 2 = disinfectant treatment

Action 3 = application of microbial antagonists

Action $4=$ cold storage, modified or controlled atmosphere storage or packaging

ical control alone is not quite popular and less desirable in Indonesia because their effectiveness as inhibitors are lower than synthetic pesticides. The biological control is also biodegradable and must be applied repeatedly.

The main objective of developing a postharvest strategy is to ensure fruit products are safe and present the lowest possible risk. Therefore, a multi-method was
Some of the problems in the supply chain include the long distance between orchards and customers and the hilly and muddy, especially when it rains. Apart from being muddy, steep roads are also a problem to reach locations. Therefore, collaboration with local governments or ministries such as the Ministry of Agriculture,

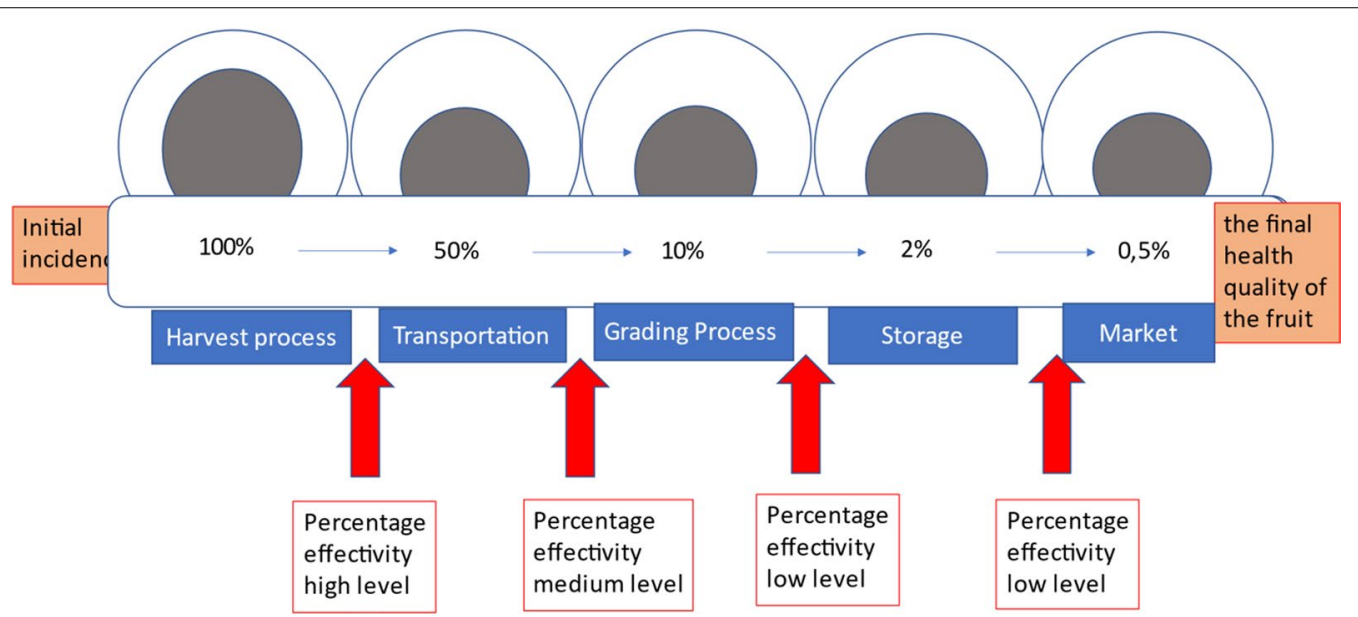

Fig. 1 Overview of assumption of strategy effectiveness of postharvest diseases control for citrus and subtropical fruits in combination and synergy 

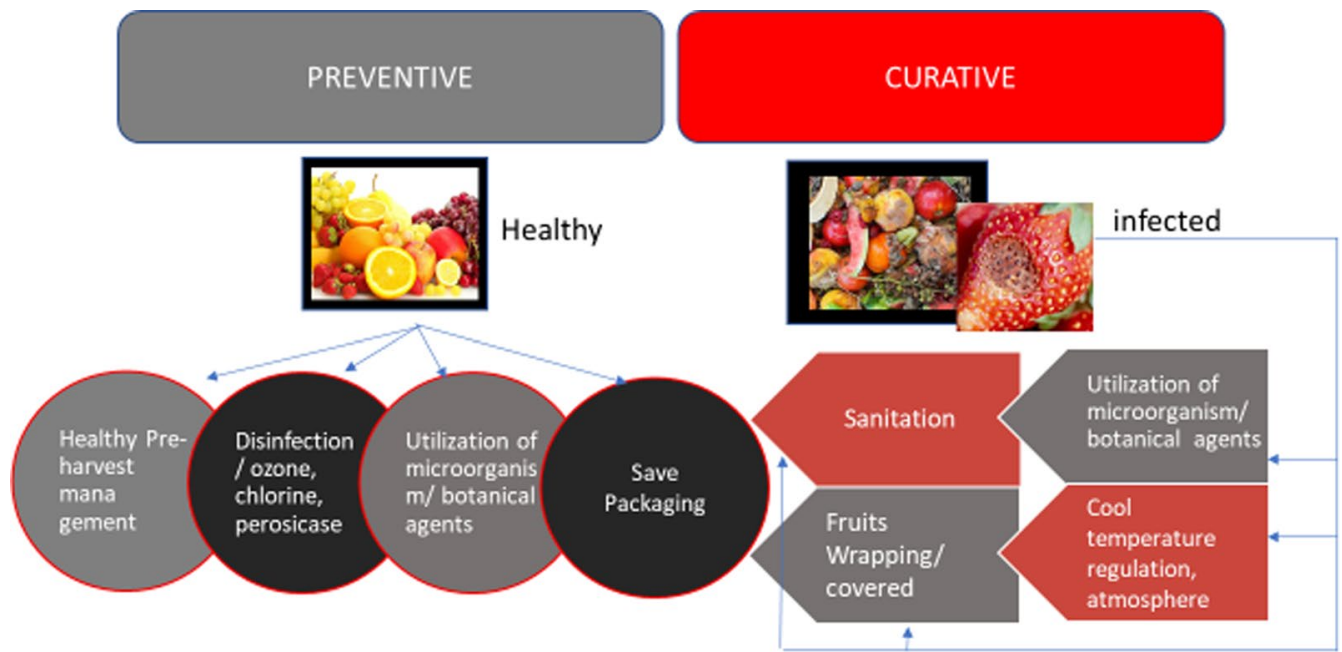

Fig. 2 Integrated postharvest disease control strategies for citrus, apples, grapes, and strawberries fruits

of Industry, of Trade and Cooperatives, and of Tourism as market owners is highly recommended. In addition, fruit-picking tourism needs to be increased by promotion, especially before the main harvest season. The strategy that can be taken to keep strawberries fresh is to handle them immediately without delay after they are harvested.

\section{Conclusions}

Among postharvest diseases of citrus and subtropical fruit (apples, grapes, strawberries) found in Indonesia, some contain mycotoxins that are harmful to human health, including Fusarium, Aspergillus sp., A. terreus, Penicillium sp., and Alternaria sp. The biological agents in the yeast group (Candida spp.) have the opportunity to be a powerful postharvest disease controller. It has been developed abroad and can be synergized with the fungal groups (Trichoderma spp.) and antagonists bacteria (Bacillus spp. and P. fluorescens) found in Indonesia that are stable and have a broad spectrum. The potential botanical agents found in Indonesia are easy to make, have a broad spectrum, and can be combined with certain biological agents and chemicals. Through mutually additive and synergistic multiple reduction methods in cooperation with the vanguards, postharvest disease control emphasizes disease prevention using several methods. Each method reduces the percentage of damage by a certain amount to produce highly effective controls.

\section{Acknowledgements}

Not applicable.

Authors' contributions

All authors contributed equally to the work.
Funding

Not applicable.

Availability of data and material

This manuscript is a review article and all the literatures cited in the manuscript are stated in "References".

\section{Declarations}

Ethics approval and consent to participate Not applicable.

\section{Consent for publication}

Not applicable.

\section{Competing interests}

The authors declare that they have no competing interests.

\section{Author details}

${ }^{1}$ Indonesian Citrus and Subtropical Fruit Research Institute, Jl. Raya Tlekung No. 1, Junrejo, Batu City, East Java, Indonesia. ²Universitas Jenderal Soedirman, Purwokerto, Jl. Dr. Suparno, Karangwangkal, Purwokerto, Banyumas Regency, Central Java, Indonesia.

Received: 28 June 2021 Accepted: 23 October 2021

Published online: 02 November 2021

\section{References}

Abd-El-Kareem F, Elshahawy IE, Abd-Elgawad MMM (2021) Application of Bacillus pumilus isolates for management of black rot disease in strawberry. Egypt J Biol Pest Control 31:25. https://doi.org/10.1186/ s41938-021-00371-z

Abo-Elyousr KAM, Al-Qurashi AD, Almasoudi NM (2021) Evaluation of the synergy between Schwanniomyces vanrijiae and propolis in the control of Penicillium digitatum on lemons. Egypt J Biol Pest Control 31:66. https:// doi.org/10.1186/s41938-021-00415-4

Benhamou N (2004) Potential of the mycoparasite, Verticillium lecanii, to protect citrus fruit against Penicillium digitatum, the causal agent of green mold: a comparison with the effect of chitosan. Phytopathology 94:693-705. https://doi.org/10.1094/PHYTO.2004.94.7.693 
Bradford KJ, Dahal P, Van Asbrouck J, Kunusoth K, Bello P, Thompson J, Wu F (2018) The dry chain: reducing postharvest losses and improving food safety in humid climates. Trends Food Sci Technol 71:84-93. https://doi. org/10.1016/j.tifs.2017.11.002

Calvo H, Marco P, Blanco D, Oria R, Venturini ME (2017) Potential of a new strain of Bacillus amyloliquefaciens BUZ-14 as a biocontrol agent of postharvest fruit diseases. Food Microbiol 63:101-110. https://doi.org/10.1016/j.fm. 2016.11 .004

Civello PM, Vicente AR, Martínez GA (2006) UV-C technology to control postharvest diseases of fruits and vegetables. In: Troncoso-Rojas R, Tiznado-Hernández ME, González-León A (eds) Recent advances in alternative postharvest technologies to control fungal diseases in fruits and vegetables. Transworld Research Network, Trivandrum, pp 71-102

de Oliveira Filho JG, da Cruz SG, Cipriano L, Gomes M, Egea MB (2021) Control of postharvest fungal diseases in fruits using external application of RNAi. J Food Sci 86:3341-3348. https://doi.org/10.1111/1750-3841.15816

Droby S, Vinokur V, Weiss B, Cohen L, Daus A, Goldschmidt EE, Porat R (2002) Induction of resistance to Penicillium digitatum in grapefruit by the yeast biocontrol agent Candida oleophila. Phytopathology 92:393-399. https:// doi.org/10.1094/PHYTO.2002.92.4.393

Dwiastuti ME, Aji TG (2021) Citrus stem rot disease (Lasiodiplodia theobromae (Pat.) Griff. \& Maubl) problem and their control strategy in Indonesia. IOP Conf Ser Earth Environ Sci 752:012030. https://doi.org/10.1088/17551315/752/1/012030

Dwiastuti ME, Fajrin MN (2014) Root and crown rot disease of strawberry (Fragaria $x$ ananassa Dutch.) and its biological agents. Prosiding Seminar Nasional PERHORTI 2014:128-135

Dwiastuti ME, Fajri M, Yunimar (2016) Potential of Trichoderma spp. as a control agents of Fusarium spp. pathogens on strawberry (Fragaria $x$ ananassa Dutch). J Hortik 25:331-339. https://doi.org/10.21082/jhort.v25n4.2015. p331-339

Evangelista-Martínez Z, Contreras-Leal EA, Corona-Pedraza LF, GastélumMartínez É (2020) Biocontrol potential of Streptomyces sp. CACIS-1.5CA against phytopathogenic fungi causing postharvest fruit diseases. Egypt $J$ Biol Pest Control 30:117. https://doi.org/10.1186/s41938-020-00319-9

Forges M, Bardin M, Urban L, Aarrouf J, Charles F (2020) Impact of UV-C radiation applied during plant growth on pre- and postharvest disease sensitivity and fruit quality of strawberry. Plant Dis 104:3239-3247. https://doi. org/10.1094/PDIS-02-20-0306-RE

El Ghaouth A, Wilson C, Wisniewski M, Droby S, Smilanick JL, Korsten L (2002) Biological control of postharvest diseases of fruits and vegetables. In: Biological Control. pp 219-238

Gu KX, Song X, Xiao XM, Duan XX, Wang JX, Duan YB, Hou YP, Zhou MG (2019) A $\beta 2$-tubulin dsRNA derived from Fusarium asiaticum confers plant resistance to multiple phytopathogens and reduces fungicide resistance. Pestic Biochem Physiol 153:36-46. https://doi.org/10.1016/j.pestbp.2018. 10.005

Hawkins NJ, Bass C, Dixon A, Neve P (2019) The evolutionary origins of pesticide resistance. Biol Rev 94:135-155. https://doi.org/10.1111/brv.12440

He CN, Ye WQ, Zhu YY, Zhou WW (2020) Antifungal activity of volatile organic compounds produced by Bacillus methylotrophicus and Bacillus thuringiensis against five common spoilage fungi on loquats. Molecules 25:3360. https://doi.org/10.3390/molecules25153360

Hendriadi A, Sulistiyorini S, Devilana MR (2021) Pesticides residues in fresh food of plant origin: case study in Indonesia. Agrivita J Agric Sci 43:285-299. https://doi.org/10.17503/agrivita.v43i2.2570

Islam MT, Sherif SM (2020) RNAi-based biofungicides as a promising nextgeneration strategy for controlling devastating gray mold diseases. Int J Mol Sci 21:2072. https://doi.org/10.3390/ijms21062072

Ismaiel A, Papenbrock J (2015) Mycotoxins: producing fungi and mechanisms of phytotoxicity. Agriculture 5:492-537. https://doi.org/10.3390/ agriculture 5030492

Khalil Bagy HMM, Ibtesam BFM, Abou-Zaid EAA, Sabah BM, Nashwa SMA (2021) Control of green mold disease using chitosan and its effect on orange properties during cold storage. Arch Phytopathol Plant Prot 54:570-585. https://doi.org/10.1080/03235408.2020.1847568

Lanier C, Garon D, Heutte N, Kientz V, André V (2020) Comparative toxigenicity and associated mutagenicity of Aspergillus fumigatus and Aspergillus flavus group isolates collected from the agricultural environment. Toxins (basel) 12:458. https://doi.org/10.3390/toxins12070458
Lass-Florl C, Griff K, Mayr A, Petzer A, Gastl G, Bonatti H, Freund M, Kropshofer G, Dierich MP, Nachbaur D (2005) Epidemiology and outcome of infections due to Aspergillus terreus: 10-year single centre experience. Br J Haematol 131:201-207. https://doi.org/10.1111/j.1365-2141.2005. 05763.x

Layton C, Maldonado E, Monroy L, Corrales Ramírez MSC LC, Sánchez Leal MSC LC (2011) Bacillus spps.; perspectiva de su efecto biocontrolador mediante antibiosis en cultivos afectados por fitopatógenos. Nova 9:177. https://doi.org/10.22490/24629448.501

Liu X, Wang J, Gou P, Gou P, Mao C, Zhu Z-R, Li H (2007) In vitro inhibition of postharvest pathogens of fruit and control of gray mold of strawberry and green mold of citrus by aureobasidin A. Int J Food Microbiol 119:223-229. https://doi.org/10.1016/j.ijfoodmicro.2007.07.054

Liu J, Sui Y, Wisniewski M, Droby S, Liu Y (2013) Review: Utilization of antagonistic yeasts to manage postharvest fungal diseases of fruit. Int J Food Microbiol 167:153-160. https://doi.org/10.1016/j.iffoodmicro.2013.09. 004

Long CA, Deng BX, Deng XX (2006) Pilot testing of Kloeckera apiculata for the biological control of postharvest diseases of citrus. Ann Microbiol 56:13-17. https://doi.org/10.1007/BF03174963

Lucon CMM, Guzzo SD, de Jesus CO, Pascholati SF, de Goes A (2010) Postharvest harpin or Bacillus thuringiensis treatments suppress citrus black spot in 'Valencia' oranges. Crop Prot 29:766-772. https://doi.org/10.1016/j. cropro.2010.02.018

Luna E, Beardon E, Ravnskov S, Ravnskov S, Scholes J, Ton J (2016) Optimizing chemically induced resistance in tomato against Botrytis cinerea. Plant Dis 100:704-710. https://doi.org/10.1094/PDIS-03-15-0347-RE

Madbouly AK, Abo Elyousr KAM, Ismail IM (2020) Biocontrol of Monilinia fructigena, causal agent of brown rot of apple fruit, by using endophytic yeasts. Biol Control 144:104239. https://doi.org/10.1016/j.biocontrol.2020. 104239

Mauch-Mani B, Baccelli I, Luna E, Flors V (2017) Defense priming: an adaptive part of induced resistance. Annu Rev Plant Biol 68:485-512. https://doi. org/10.1146/annurev-arplant-042916-041132

Mercier J, Smilanick JL (2005) Control of green mold and sour rot of stored lemon by biofumigation with Muscodor albus. Biol Control 32:401-407. https://doi.org/10.1016/j.biocontrol.2004.12.002

Mercier J, Jiménez-Santamaría JI, Tamez-Guerra P (2007) Development of the volatile-producing fungus Muscodor albus worapong, strobel, and hess as a novel antimicrobial biofumigant. Rev Mex Fitopatol 25:173-179

Meziane H, Gavriel S, Ismailov Z, Chet I, Chernin L, Höfte M (2006) Control of green and blue mould on orange fruit by Serratia plymuthica strains IC14 and IC1270 and putative modes of action. Postharvest Biol Technol 39:125-133. https://doi.org/10.1016/j.postharvbio.2005.10.007

Miskiyah CW, Broto W (2010) Mycotoxin contamination in fresh fruit and its processed products and their prevention. J Litbang Pertan 29:79-85

Mohammadi P, Tozlu E, Kotan R, Şenol Kotan M (2017) Potential of some bacteria for biological control of postharvest citrus green mould caused by Penicillium digitatum. Plant Prot Sci 53:134-143. https://doi.org/10. 17221/55/2016-PPS

Nabi SU, Raja WH, Kumawat KL, Mir Jl, Sharma OC, Singh DB, Sheikh MA (2017) Post harvest diseases of temperate fruits and their management strategies_a review. Int J Pure Appl Biosci 5:885-898. https://doi.org/10. 18782/2320-7051.2981

Navarro-Herrera YY, Ortíz-Moreno ML (2020) Yeast strains with antagonist activity against Colletotrichum gloeosporioides (Penz.) Penz. \& Sacc. and their phenotypic characterization. Egypt J Biol Pest Control 30:29. https:// doi.org/10.1186/s41938-020-00231-2

Pal S, Singh N, Ansari KM (2017) Toxicological effects of patulin mycotoxin on the mammalian system: an overview. Toxicol Res (camb) 6:764-771. https://doi.org/10.1039/c7tx00138j

Parafati L, Vitale A, Polizzi G, Restuccia C, Cirvilleri G (2016) Understanding the mechanism of biological control of postharvest phytopathogenic moulds promoted by food isolated yeasts. Acta Hortic 1144:93-100. https://doi. org/10.17660/ActaHortic.2016.1144.13

Perez M, Ibarreche J, Isas A, Sepulveda M, Ramallo J, Dib JR (2017) Antagonistic yeasts for the biological control of Penicillium digitatum on lemons stored under export conditions. Biol Control 115:135-140. https://doi.org/10. 1016/j.biocontrol.2017.10.006 
Pétriacq P, López A, Luna E (2018) Fruit decay to diseases: can induced resistance and priming help? Plants 7:77. https://doi.org/10.3390/plants7040 077

Platania C, Restuccia C, Muccilli S, Cirvilleri G (2012) Efficacy of killer yeasts in the biological control of Penicillium digitatum on Tarocco orange fruits (Citrus sinensis). Food Microbiol 30:219-225. https://doi.org/10.1016/j.fm. 2011.12 .010

Prabawati S (2009) Transportation, distribution and retail. In: Broto W (ed) Postharvest fruit handling technology for market. Academic Press, Cambridge, pp 69-86

Qadri R, Azam M, Khan I, Yang Y, Ejaz S, Akram MT, Khan MA (2020) Conventional and modern technologies for the management of post-harvest diseases. In: UI Haq I, ljaz S (eds) Plant disease management strategies for sustainable agriculture through traditional dan modern approaches, 13th edn. Springer, Cham, pp 137-172

Rahayu WP (2006) Mycotoxins and mycotoxic: food safety microbiology. Department of Food Science and Technology, IPB University

Ramalingam S, Bahuguna A, Kim M (2019) The effects of mycotoxin patulin on cells and cellular components. Trends Food Sci Technol 83:99-113. https://doi.org/10.1016/.j.tifs.2018.10.010

Rasmann S, De Vos M, Casteel CL, Tian D, Halitschke R, Sun JY, Agrawal AA, Felton GW, Jander G (2012) Herbivory in the previous generation primes plants for enhanced insect resistance. Plant Physiol 158:854-863. https:// doi.org/10.1104/pp.111.187831

Roberto SR, Youssef K, Hashim AF, Ippolito A (2019) Nanomaterials as alternative control means against postharvest diseases in fruit crops. Nanomaterials 9:1752. https://doi.org/10.3390/nano9121752

Rodriguez J, Anoruo A, Jifon J, Simpson C (2019) Physiological effects of exogenously applied reflectants and anti-transpirants on leaf temperature and fruit sunburn in citrus. Plants 8:549. https://doi.org/10.3390/plants8120 549

Sharma RR, Singh D, Singh R (2009) Biological control of postharvest diseases of fruits and vegetables by microbial antagonists: a review. Biol Control 50:205-221. https://doi.org/10.1016/j.biocontrol.2009.05.001

Siswadi (2007) Post-harvest handling of fruits and vegetables. Innofarm J Inov Pertan 6:68-71. https://doi.org/10.1128/AAC.03728-14

Sobrova P, Adam V, Vasatkova A, Beklova M, Zeman L, Kizek R (2010) Deoxynivalenol and its toxicity. Interdiscip Toxicol 3:94-99. https://doi.org/10. 2478/v10102-010-0019-x

Soesanto L (2006) Postharvest diseases: an introduction. Kanisius, Jakarta

Soesanto L (2009) Biocontrol of plant pathogens: opportunities and challenges in supporting sustainable food security. Professor Inauguration Speech

Spadaro D (2012) Biological control of postharvest diseases of fruits and vegetables. In: Agricultural Sciences, Encyclopedia of Life Support Systems (EOLSS), Developed under the Auspices of the UNESCO. Eolss Publishers, Oxford

Stockwell VO, Stack JP (2007) Using Pseudomonas spp. for integrated biological control. Phytopathology 97:244-249. https://doi.org/10.1094/ PHYTO-97-2-0244

Strobel GA, Dirkse E, Sears J, Markworth C (2001) Volatile antimicrobials from Muscodor albus, a novel endophytic fungus. Microbiology 147:2943-2950
Sudjatha W, Wisaniyasa NW (2017) Postharvest physiology and technology (fruits and vegetables). Udayana University Press, Denpasar

Sui Y, Wisniewski M, Droby S, Liu J (2015) Responses of yeast biocontrol agents to environmental stress. Appl Environ Microbiol 81:2968-2975. https:// doi.org/10.1128/AEM.04203-14

Sukasih E, Setyadjit (2019) Fresh handling techniques for strawberry to maintain its quality. J Penelit dan Pengemb Pertan 38:47. https://doi.org/10. 21082/jp3.v38n1.2019.p47-54

Sumiati A, Julianto RPD (2017) Analysis of pesticide residues in sweet oranges in Dau District, Malang. Buana Sains 17:19-24. https://doi.org/10.33366/ bs.v17i1.574

Verma M, Brar S, Tyagi R, Surampalli RY, Valéro JR (2007) Antagonistic fungi, Trichoderma spp.: Panoply of biological control. Biochem Eng J 37:1-20. https://doi.org/10.1016/j.bej.2007.05.012

Wallace RL, Hirkala DL, Nelson LM (2018) Mechanisms of action of three isolates of Pseudomonas fluorescens active against postharvest grey mold decay of apple during commercial storage. Biol Control 117:13-20. https://doi.org/10.1016/j.biocontrol.2017.08.019

Wang M, Weiberg A, Lin F, Thomma BPHJ, Huang HD, Jin H (2016) Bidirectional cross-kingdom RNAi and fungal uptake of external RNAs confer plant protection. Nat Plants. https://doi.org/10.1038/nplants.2016.151

Wei Y, Mao S, Tu K (2014) Effect of preharvest spraying Cryptococcus laurentii on postharvest decay and quality of strawberry. Biol Control 73:68-74. https://doi.org/10.1016/j.biocontrol.2014.02.016

Widiastuti A, Ningtyas OH, Priyatmojo A (2015) Identification of fungus causing postharvest disease on several fruits in Yogyakarta. J Fitopatol Indones 11:91-96. https://doi.org/10.14692/jfi.11.3.91

Yánez-Mendizábal V, Usall J, Viñas I, Casals C, Marín S, Solsona C, Teixidó N (2011) Potential of a new strain of Bacillus subtilis CPA-8 to control the major postharvest diseases of fruit. Biocontrol Sci Technol 21:409-426. https://doi.org/10.1080/09583157.2010.541554

Youssef K, Roberto S, Tiepo A, Constantino LV, de Resende JTV, Abo-Elyousr KAM (2020) Salt solution treatments trigger antioxidant defense response against gray mold disease in table grapes. J Fungi 6:179. https://doi.org/ 10.3390/jof6030179

Yu T, Wang L, Yin Y, Wang Y, Zheng X (2008) Effect of chitin on the antagonistic activity of Cryptococcus laurentii against Penicillium expansum in pear fruit. Int J Food Microbiol 122:44-48. https://doi.org/10.1016/j.ijfoodmicro. 2007.11.059

Zain ME (2011) Impact of mycotoxins on humans and animals. J Saudi Chem Soc 15:129-144. https://doi.org/10.1016/j.jscs.2010.06.006

Zhang Z, Li S, Sun D, Yang Y, Wei Z, Wang C, Lu L (2021) Cultivation of Rhodosporidium paludigenum in gluconic acid enhances effectiveness against Penicillium digitatum in citrus fruit. Postharvest Biol Technol 172:111374. https://doi.org/10.1016/j.postharvbio.2020.111374

\section{Publisher's Note}

Springer Nature remains neutral with regard to jurisdictional claims in published maps and institutional affiliations.

\section{Submit your manuscript to a SpringerOpen ${ }^{\circ}$ journal and benefit from:}

- Convenient online submission

- Rigorous peer review

- Open access: articles freely available online

- High visibility within the field

- Retaining the copyright to your article

Submit your next manuscript at $\boldsymbol{\nabla}$ springeropen.com 